\title{
Humibacillus xanthopallidus gen. nov., sp. nov.
}

Correspondence

Yoko Takahashi

ytakaha@lisci.kitasato-u.ac.jp

\author{
Akiko Kageyama, ${ }^{1}$ Atsuko Matsumoto, ${ }^{1,2}$ Satoshi Ōmura ${ }^{1,2}$ \\ and Yoko Takahashi ${ }^{1}$ \\ ${ }^{1}$ Kitasato Institute for Life Sciences, Kitasato University, 5-9-1 Shirokane, Minato-ku, Tokyo 108- \\ 8642, Japan \\ ${ }^{2}$ The Kitasato Institute, 5-9-1 Shirokane, Minato-ku, Tokyo 108-8642, Japan
}

The family Intrasporangiaceae Rainey et al. 1997 was proposed by Stackebrandt et al. (1997) and the description of the family was later emended by Stackebrandt \& Schumann (2000). At the time of writing, the family comprised 13 genera, and could be divided into three groups based on the occurrence of LL-diaminopimelic acid $\left(\mathrm{A}_{2} \mathrm{pm}\right)$, meso- $\mathrm{A}_{2} \mathrm{pm}$ or $\mathrm{L}$-ornithine as the diagnostic diamino acid in the cell-wall peptidoglycan. Two novel strains within the family are described herein. Strain $\mathrm{KV}-663^{\mathrm{T}}$ was isolated from the same soil sample from which strains of the recently described genus Oryzihumus (Kageyama et al., 2005) were obtained. In contrast, strain YM21-029 was isolated from a sediment sample collected in Japan by using HSV agar plates. The components of the HSV medium are detailed in Supplementary Table S1 (see IJSEM Online). Humic acid was purchased from Acros Organics Inc. and was purified according to the protocol of the International Humic Substances Society (http:// www.ihss.gatech.edu/soilhafa.html). Strains $\mathrm{KV}-663^{\mathrm{T}}$ and YM21-029 were isolated from different sources and by using two different methods. However, morphological, physiological and biochemical characteristics, $16 \mathrm{~S}$ rRNA

\section{Abbreviation: $A_{2}$ pm, LL-diaminopimelic acid.}

The GenBank/EMBL/DDBJ accession numbers for the 16S rRNA gene sequences of strains $\mathrm{KV}-663^{\top}$ and $\mathrm{YM} 21-029$ are AB282888 and AB286022, respectively.

A table detailing the components of medium HSV is available with the online version of this paper. gene sequence analysis and DNA-DNA hybridization experiments revealed that the two strains represented a single novel species of a new genus.

Strain $\mathrm{KV}-663^{\mathrm{T}}$ was isolated from a soil sample collected from a paddy field in Saitama Prefecture, Japan. A 2 g soil sample was suspended in $18 \mathrm{ml}$ sterile water and mixed. Soil particles were allowed to sediment, the liquid phase was then diluted $10^{5}$-fold and $100 \mu \mathrm{l}$ of the liquid was spread onto the surfaces of GPM agar plates (per litre: $10 \mathrm{~g}$ glucose, $5 \mathrm{~g}$ peptone, $5 \mathrm{~g}$ meat extract, $3 \mathrm{~g} \mathrm{NaCl}, 12 \mathrm{~g}$ agar; $\mathrm{pH}$ 7.0) (Takahashi et al., 2003). The plates were cultured at $27{ }^{\circ} \mathrm{C}$. Strain YM21-029 was isolated from a sediment sample collected from Lake Jusanko, Aomori Prefecture, Japan (depth, $20 \mathrm{~cm}$; GPS location, $41^{\circ} 59^{\prime} 48.8^{\prime \prime} \mathrm{N} 140^{\circ}$ $\left.21^{\prime} 33.2^{\prime \prime} \mathrm{E}\right)$, in September 2005. The samples $\left(0.5-1 \mathrm{~cm}^{3}\right)$ were homogenized and suspended in $5 \mathrm{ml}$ sterile seawater. Strain YM21-029 was isolated on HSV medium, by using a $50 \mu \mathrm{l}$ sample of the suspension, and the plate was cultured at $25{ }^{\circ} \mathrm{C}$ for 30 days. Biomass for biochemical and chemotaxonomic studies was prepared by culturing the strains in trypticase soy broth (TSB; Difco) at $27{ }^{\circ} \mathrm{C}$ for 3 or 4 days.

Morphological observation via a scanning electron microscope (JSM-5600; JEOL) was performed on cultures grown on GPM agar medium at $27{ }^{\circ} \mathrm{C}$ for 2 days. The ability of each strain to grow on a range of sole carbon sources at $1 \%$ $(\mathrm{w} / \mathrm{v})$ was determined by using carbon utilization media (Pridham \& Gottlieb, 1948). Tolerance of $\mathrm{NaCl}$ and $\mathrm{pH}$ 
and temperature ranges for growth were determined on one-fifth-strength nutrient agar. The two isolates were characterized biochemically by using the API ZYM system in accordance with the manufacturer's instructions (bioMérieux). Assimilation of sugars by strain $\mathrm{KV}-663^{\mathrm{T}}$ was determined by using the API $50 \mathrm{CH}$ system (bioMérieux).

Whole-cell hydrolysates were analysed for $\mathrm{A}_{2} \mathrm{pm}$ isomers by using TLC (Hasegawa et al., 1983). Purified cell walls were obtained according to the method of Kawamoto et al. (1981). A $1 \mathrm{mg}$ sample of purified cell wall was hydrolysed at $100{ }^{\circ} \mathrm{C}$ with $1 \mathrm{ml} 6 \mathrm{M} \mathrm{HCl}$ for $16 \mathrm{~h}$. The residue was dissolved in $100 \mu \mathrm{l}$ water and this solution was used for amino acid analysis. The amino acid composition was determined by HPLC by using the Pico Tag method (Waters). Samples were derivatized with phenylisothiocyanate and UV $(254 \mathrm{~nm})$ detection was used. The presence of mycolic acids was assessed by using the TLC method of Tomiyasu (1982). Polar lipid profiles were determined by TLC (Minnikin et al., 1977). Whole-cell sugars were identified by the method described by Becker et al. (1965). Menaquinones were extracted and purified according to Collins et al. (1977) and then analysed by HPLC (802-SC; Jasco) by using a chromatograph equipped with a Capcell Pak C18 column (Shiseido) (Tamaoka et al., 1983). Methyl esters of cellular fatty acids were prepared and analysed by GLC (HP6890; Hewlett Packard).

DNA base composition and levels of DNA-DNA relatedness were determined. DNA was isolated as described by Saito \& Miura (1963), with some modifications. DNA base composition was estimated by HPLC (Tamaoka \& Komagata, 1984). Levels of DNA-DNA relatedness were determined by using the method of Ezaki et al. (1989).

DNA was prepared by sonication (Yu et al., 2002) or by using the InstaGene matrix (Bio-Rad). The 16S rRNA gene was amplified by PCR and sequenced with an automatic sequence analyser (ABI Prism 3130 or 3730; PE Applied Biosystems) by using a dye terminator cycle sequencing kit (PE Applied Biosystems).
Species related to the novel isolates were identified by performing sequence database searches with the BLAST program (Altschul et al., 1990). Sequence data of related species were retrieved from GenBank. Nucleotide substitution rates ( $K_{\text {nuc }}$ values) were calculated (Kimura \& Ohta, 1972) and phylogenetic trees were constructed by using the neighbour-joining method (Saitou \& Nei, 1987). Statistical significance of the tree topology was evaluated by bootstrap analysis of sequence data by using CLUSTAL W software (Thompson et al., 1994). Sequence similarity values were determined by visual comparison and manual calculation.

Nearly-complete 16S rRNA gene sequences were determined for the two isolated strains. A database search demonstrated that these strains belonged to the suborder Micrococcineae of the family Intrasporangiaceae. It was clear from the phylogenetic tree (Fig. 1) that the two strains formed a monophyletic clade that was associated with Intrasporangium calvum and Terracoccus luteus. Strains KV-663 ${ }^{\mathrm{T}}$ and YM21-029 shared a 16S rRNA gene sequence similarity of $99.2 \%$; levels of sequence similarity between strain $\mathrm{KV}-663^{\mathrm{T}}$ and the type strains of Intrasporangium calvum, Terracoccus luteus and Arsenicicoccus bolidensis were 97.4, 97.8 and $93.8 \%$, respectively.

The DNA base composition of the novel isolates was 69$70 \mathrm{~mol} \% \mathrm{G}+\mathrm{C}$ based on HPLC of nucleosides. The cellwall peptidoglycan of strain $\mathrm{KV}-663^{\mathrm{T}}$ contained glutamic acid, glycine, alanine and $\mathrm{LL}_{-} \mathrm{A}_{2} \mathrm{pm}$ at a molar ratio of $1: 1.7: 1.3: 0.8$. The polar lipid of strain $\mathrm{KV}-663^{\mathrm{T}}$ was phosphatidylethanolamine. Whole-cell sugars of strain $\mathrm{KV}-663^{\mathrm{T}}$ were galactose, glucose and rhamnose. The two novel isolates had peptidoglycan of type A3 $\gamma$ (Schleifer \& Kandler, 1972). The predominant menaquinone was MK$8\left(\mathrm{H}_{4}\right)$ (about $\left.90 \%\right)$. Mycolic acids were not detected. The cellular fatty acids of strains $\mathrm{KV}-633^{\mathrm{T}}$ and YM21-029 were iso- $\mathrm{C}_{14: 0}$ (4.4 and 6.0\%, respectively), iso- $\mathrm{C}_{15: 0}$ (39.7 and $34.9 \%)$, anteiso- $\mathrm{C}_{15: 0}(8.1$ and $11.1 \%)$, iso- $\mathrm{C}_{16: 0}$ (8.0 and $8.8 \%)$, iso- $\mathrm{C}_{17: 0}(4.4$ and $4.1 \%)$, anteiso- $\mathrm{C}_{14: 0}(4.2$ and $5.8 \%), \mathrm{C}_{17: 1} \omega 8 c(7.5$ and $5.7 \%), \mathrm{C}_{17: 0}$ (4.0 and $5.7 \%)$ and $\mathrm{C}_{18: 1} \omega 9 c(4.3$ and $3.7 \%)$. The predominant cellular fatty acid component was iso- $\mathrm{C}_{15: 0}$. Strain

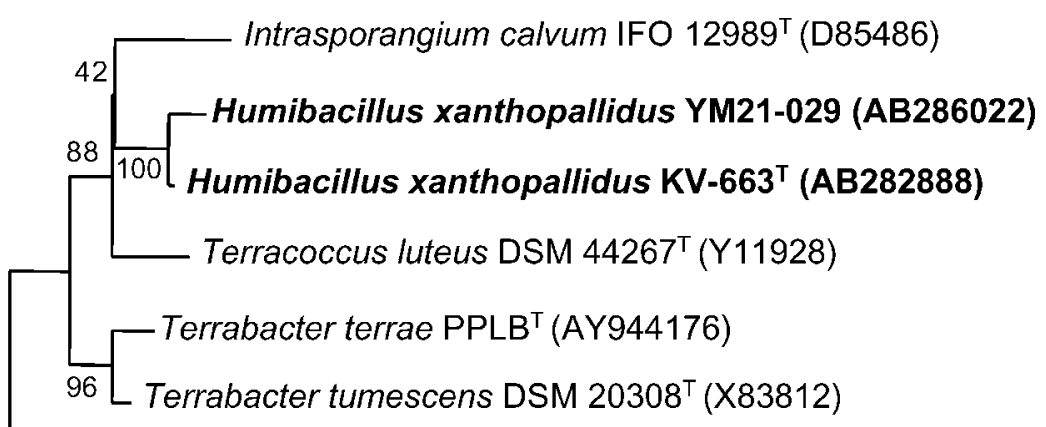

Janibacter limosus DSM $11140^{\top}$ (Y08539)

0.002
Fig. 1. Phylogenetic tree showing the position of strains $\mathrm{KV}-663^{\top}$ and $\mathrm{YM} 21-029$ derived from 16S rRNA gene sequences and constructed according to the neighbour-joining method and $K_{\text {nuc }}$ values. Numbers at the branch points are bootstrap values (1000 resamplings). The tree was unrooted and Janibacter limosus DSM $11140^{\top}$ was used as an outgroup. Bar, $0.002 K_{\text {nuc. }}$. 
$\mathrm{KV}-663^{\mathrm{T}}$ was able to assimilate glycerol, ribose, glucose, fructose, mannose, mannitol, maltose, sucrose and trehalose, but not 40 other compounds in the API 50CH system.

Of the 13 recognized genera within the family Intrasporangiaceae, Arsenicicoccus (Collins et al., 2004), Intrasporangium (Kalakoutskii et al., 1967), Terrabacter (Collins et al., 1989) and Terracoccus (Prauser et al., 1997) have LL- $\mathrm{A}_{2} \mathrm{pm}$ in their cell walls. Differential characteristics between strains KV-663 ${ }^{\mathrm{T}}$ and YM21-029 and LL- $\mathrm{A}_{2} \mathrm{pm}-$ containing members of the family Intrasporangiaceae are detailed in Table 1. The major cellular fatty acids of strains KV-663 ${ }^{\mathrm{T}}$ and YM21-029 were a complex mixture of straight-chain saturated, monounsaturated, and iso- and anteiso-methyl-branched acids. Members of the genus Arsenicicoccus show the same major cellular fatty acid profile, but differ with respect to cell morphology and the number of glycine residues in the peptidoglycan. Strain $\mathrm{KV}-663^{\mathrm{T}}$ has two glycine residues within the peptidoglycan. In contrast, Arsenicicoccus has a single glycine residue within the murein interpeptide bridge, whereas the genera Intrasporangium, Terrabacter and Terracoccus have three glycine residues within the murein interpeptide bridge (Collins et al., 2004). Given these observations, we suggest that strains $\mathrm{KV}-663^{\mathrm{T}}$ and YM21-029 belong to a new genus in the family Intrasporangiaceae.

In order to confirm that these two strains belong to the same species, DNA-DNA hybridization experiments were performed (duplicate procedures). Levels of relatedness between strains $\mathrm{KV}-663^{\mathrm{T}}$ and YM21-029 were $77-78 \%$, indicating that they belong to the same species.

The two novel strains were also examined for a range of phenotypic and chemotaxonomic characteristics. Physiological characteristics are provided in the species description below.

Based on their distinct phylogenetic position within the family Intrasporangiaceae, together with characteristic cell morphology, fatty acid composition and cell-wall murein type, strains $\mathrm{KV}-663^{\mathrm{T}}$ and YM21-029 are considered to represent a novel species of a new genus, for which the name Humibacillus xanthopallidus gen. nov., sp. nov. is proposed.

\section{Description of Humibacillus gen. nov.}

Humibacillus (Hu.mi.ba.cil'lus. L. fem. n. humus soil; L. masc. n. bacillus rod; N.L. masc. n. Humibacillus rod isolated from soil).

Gram-positive, catalase-positive, aerobic, irregular rods. The peptidoglycan is of $\mathrm{A} 3 \gamma$ type, containing $\mathrm{LL}-\mathrm{A}_{2} \mathrm{pm}$, glycine, alanine and glutamic acid. Mycolic acids are absent. The major menaquinone is $\mathrm{MK}-8\left(\mathrm{H}_{4}\right)$. The major cellular fatty acids are a complex mixture of straight-chain saturated, monounsaturated, and iso- and anteiso-methylbranched components. The DNA G $+\mathrm{C}$ content is 69$70 \mathrm{~mol} \%$. Phylogenetically, the genus is a member of the family Intrasporangiaceae, suborder Micrococcineae. With regard to signature nucleotides defined for the family Intrasporangiaceae, at pair positions 1134 to 1140 strain $\mathrm{KV}-663^{\mathrm{T}}$ has an $\mathrm{A}-\mathrm{U}$ rather than a $\mathrm{G}-\mathrm{C}$ pair. The type species is Humibacillus xanthopallidus.

\section{Description of Humibacillus xanthopallidus sp. nov.}

Humibacillus xanthopallidus (xan.tho.pal'li.dus. Gr. adj. xanthos yellow; L. adj. pallidus pale; N.L. masc. adj. xanthopallidus pale yellow).

Cells have diameters of $0.4-1.1 \times 1.1-1.9 \mu \mathrm{m}$ (Fig. 2). Colonies are pale yellow. Growth occurs between $\mathrm{pH} 5$ and 11 (optimal is $\mathrm{pH} 7$ ), and between 7 and $32{ }^{\circ} \mathrm{C}$ (optimal temperatures are 27 and $32{ }^{\circ} \mathrm{C}$ for strains $\mathrm{KV}-663^{\mathrm{T}}$ and YM21-029, respectively). In one-fifth-strength nutrient agar medium, growth occurs at up to $3 \%(\mathrm{w} / \mathrm{v}) \mathrm{NaCl}$. Assimilates D-galactose, D-glucose, D-mannitol, D-mannose, raffinose, L-rhamnose, sucrose and trehalose, but not L-arabinose, D-fructose, maltose or D-xylose. Alkaline phosphatase, esterase (C4), esterase lipase (C8), leucine arylamidase, acid phosphatase, naphthol-AS-BI-phosphohydrolase, $\alpha$-galactosidase, $\beta$-galactosidase, $\alpha$-glucosidase and $\beta$-glucosidase are detected with the API ZYM enzyme assay; negative for $N$-acetyl- $\beta$-glucosaminidase and $\alpha$ fucosidase. Weakly positive for lipase (C14). The DNA $\mathrm{G}+\mathrm{C}$ content is $69-70 \mathrm{~mol} \%$.

Table 1. Differential characteristics between strains $\mathrm{KV}-663^{\top}, \mathrm{YM} 21-029$ and LL-diaminopimelic-acid-containing members of the family Intrasporangiaceae

Taxa: 1, strains KV-663 ${ }^{\mathrm{T}}$ and YM21-029; 2, Arsenicicoccus (data from Collins et al., 2004); 3, Intrasporangium (Schumann et al., 1997); 4, Terrabacter (Martin et al., 1997); 5, Terracoccus (Prauser et al., 1997). All taxa have LL-A 2 pm as the cell-wall diamino acid.

\begin{tabular}{|c|c|c|c|c|c|}
\hline Characteristic & 1 & 2 & 3 & 4 & 5 \\
\hline DNA G $+C$ content $(\mathrm{mol} \%)$ & $69-70$ & 72 & 68 & $70-73$ & 73 \\
\hline Fatty acid type & SAIU & SAIU & SAI & SAI & SAI \\
\hline
\end{tabular}

${ }^{\star}$ A, anteiso methyl branched; I, iso methyl branched; S, straight-chain saturated; U, monounsaturated. 


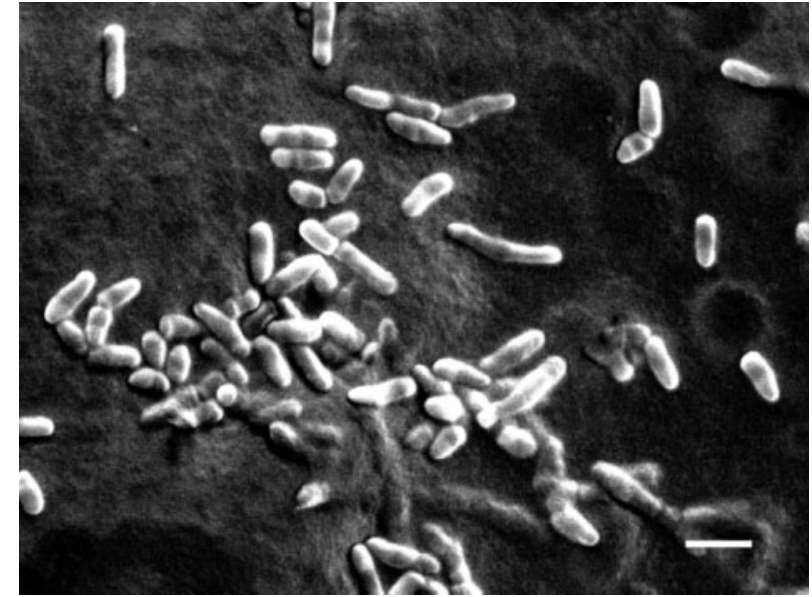

Fig. 2. Scanning electron micrograph of cells from a 2-day-old culture of strain $\mathrm{KV}-663^{\top}$ grown on GPM agar medium at $27^{\circ} \mathrm{C}$. Bar, $2 \mu \mathrm{m}$.

The type strain, KV-663 ${ }^{\mathrm{T}} \quad\left(=\mathrm{NRRL} \quad \mathrm{B}-24471^{\mathrm{T}}=\mathrm{NBRC}\right.$ $101803^{\mathrm{T}}$ ), was isolated from a soil sample collected from a paddy field. YM21-029, isolated from lake sediment, is a second strain of the species.

\section{Acknowledgements}

This study was supported in part by a grant of the 21st Century COE Program from the Ministry of Education, Culture, Sports, Science and Technology (MEXT) and The JSPS Grant-in-Aid for Science Research foundation. We thank Dr Yoshihide Matsuo, Marine Biotechnology Institute, for the provision of strain YM21-029 and data regarding its isolation. Isolation and phylogenetic identification of strain YM21-029 was supported by the New Energy and Industrial Technology Development Organization (NEDO). We thank Hayashi Nobuyuki in our laboratory for identification of cell-wall amino acids.

\section{References}

Altschul, S. F., Gish, W., Miller, W., Myers, E. W. \& Lipman, D. J. (1990). Basic local alignment search tool. J Mol Biol 215, 403-410.

Becker, B., Lechevalier, M. P. \& Lechevalier, H. A. (1965). Chemical composition of cell-wall preparation from strains of various formgenera of aerobic actinomycetes. Appl Microbiol 13, 236-243.

Collins, M. D., Pirouz, T., Goodfellow, M. \& Minnikin, D. E. (1977). Distribution of menaquinones in actinomycetes and corynebacteria. J Gen Microbiol 100, 221-230.

Collins, M. D., Dorsch, M. \& Stackebrandt, E. (1989). Transfer of Pimelobacter tumescens to Terrabacter gen. nov. as Terrabacter tumescens comb. nov. and of Pimelobacter jensenii to Nocardioides as Nocardioides jensenii comb. nov. Int J Syst Bacteriol 39, 1-6.

Collins, M. D., Routh, J., Saraswathy, A., Lawson, P. A., Schumann, P., Welinder-Olsson, C. \& Falsen, E. (2004). Arsenicicoccus bolidensis gen. nov., sp. nov., a novel actinomycete isolated from contaminated lake sediment. Int J Syst Evol Microbiol 54, 605-608.

Ezaki, T., Hashimoto, Y. \& Yabuuchi, E. (1989). Fluorometric deoxyribonucleic acid-deoxyribonucleic acid hybridization in micro- dilution wells as an alternative to membrane filter hybridization in which radioisotopes are used to determine genetic relatedness among bacterial strains. Int J Syst Bacteriol 39, 224-229.

Hasegawa, T., Takizawa, M. \& Tanida, S. (1983). A rapid analysis for chemical grouping of aerobic Actinomycetes. J Gen Appl Microbiol 29, 319-322.

Kageyama, A., Takahashi, Y., Seki, T., Tomoda, H. \& Ōmura, S. (2005). Oryzihumus leptocrescens gen. nov., sp. nov. Int J Syst Evol Microbiol 55, 2555-2559.

Kalakoutskii, L. V., Kirillova, I. P. \& Krasil'Nikov, N. A. (1967). A new genus of the Actinomycetales, Intrasporangium gen. nov. J Gen Microbiol 48, 79-85.

Kawamoto, l., Oka, T. \& Nara, T. (1981). Cell wall composition of Micromonospora olivoasterospora, Micromonospora sagamiensis, and related organisms. J Bacteriol 146, 527-534.

Kimura, M. \& Ohta, T. (1972). On the stochastic model for estimation of mutation distance between homologous proteins. J Mol Evol 2, 87-90.

Martin, K., Schumann, P., Rainey, F. A., Schuetze, B. \& Groth, I. (1997). Janibacter limosus gen. nov., sp. nov., a new actinomycete with meso-diaminopimelic acid in the cell wall. Int J Syst Bacteriol 47, 529-534.

Minnikin, D. E., Patel, P. V., Alshamaony, L. \& Goodfellow, M. (1977). Polar lipid composition in the classification of Nocardia and related bacteria. Int J Syst Bacteriol 27, 104-117.

Prauser, H., Schumann, P., Rainey, F. A., Kropppenstedt, R. M. \& Stackebrandt, E. (1997). Terracoccus luteus gen. nov., sp. nov., an LLdiaminopimelic acid-containing coccoid actinomycete from soil. Int $J$ Syst Bacteriol 47, 1218-1224.

Pridham, T. G. \& Gottlieb, D. (1948). The utilization of carbon compounds by some Actinomycetales as an aid for species determination. J Bacteriol 56, 107-114.

Saito, H. \& Miura, K. I. (1963). Preparation of transforming deoxyribonucleic acid by phenol treatment. Biochim Biophys Acta 72, 619-629.

Saitou, N. \& Nei, M. (1987). The neighbor-joining method: a new method for reconstructing phylogenetic trees. Mol Biol Evol 4, 406-425.

Schleifer, K. H. \& Kandler, O. (1972). Peptidoglycan types of bacterial cell walls and their taxonomic implications. Bacteriol Rev 36, 407-477.

Schumann, P., Prauser, H., Rainey, F. A., Stackebrandt, E. \& Hirsch, P. (1997). Friedmanniella antarctica gen. nov., sp. nov., an LLdiaminopimelic acid-containing actinomycete from Antarctic sandstone. Int J Syst Bacteriol 47, 278-283.

Stackebrandt, E. \& Schumann, P. (2000). Description of Bogoriellaceae fam. nov., Dermacoccaceae fam. nov., Rarobacteraceae fam. nov and Sanguibacteraceae fam. nov. and emendation of some families of the suborder Micrococcineae. Int J Syst Evol Microbiol 50, 1279-1285.

Stackebrandt, E., Rainey, F. A. \& Ward-Rainey, N. L. (1997). Proposal for a new hierarchic classification system, Actinobacteria classis nov. Int J Syst Bacteriol 47, 479-491.

Takahashi, Y., Katoh, S., Shikura, N., Tomoda, H. \& Ōmura, S. (2003). Superoxide dismutase produced by soil bacteria increases bacterial colony growth from soil samples. J Gen Appl Microbiol 49, 263-266.

Tamaoka, J. \& Komagata, K. (1984). Determination of DNA base composition by reversed-phase high-performance liquid chromatography. FEMS Microbiol Lett 25, 125-128. 
Tamaoka, J., Katayama-Fujimura, Y. \& Kuraishi, H. (1983). Analysis of bacterial menaquinone mixtures by high performance liquid chromatography. J Appl Bacteriol 54, 31-36.

Thompson, J. D., Higgins, D. G. \& Gibson, T. J. (1994). CLUSTAL W: improving the sensitivity of progressive multiple sequence alignment through sequence weighting, position specific gap penalties and weight matrix choice. Nucleic Acids Res 22, 4673-4680.
Tomiyasu, I. (1982). Mycolic acid composition and thermally adaptative changes in Nocardia asteroides. J Bacteriol 151, 828-837.

Yu, L., Takahashi, Y., Matsumoto, A., Seino, A., Iwai, Y. \& Ōmura, S. (2002). Application of PCR for selection of gram-positive bacteria with high DNA G $+\mathrm{C}$ content among new isolates. Actinomycetologica 16, 1-5. 